\title{
OPTIMIZING OUTCOME IN THE UNIVERSITY-INDUSTRY TECHNOLOGY TRANSFER PROJECTS
}

\author{
Hamed ALAVI \\ Tallinn University of Technology \\ Patrycja HĄBEK \\ Silesian University of Technology
}

\begin{abstract}
:
Transferring inventions of academic scientists to private enterprises for the purpose of commercialization is long known as University-Industry (firm) Technology Transfer While the importance of this phenomenon is simultaneously raising in public and private sector, only a part of patented academic inventions succeed in passing the process of commercialization. Despite the fact that formal Technology Transfer process and licencing of patented innovations to third party is the main legal tool for safeguarding rights of academic inventors in commercialization of their inventions, it is not sufficient for transmitting tacit knowledge which is necessary in exploitation of transferred technology. Existence of reciprocal and complementary relations between formal and informal technology transfer process has resulted in formation of different models for university-industry organizational collaboration or even integration where licensee firms keep contact with academic inventors after gaining legal right for commercialization of their patented invention. Current paper argues that despite necessity for patents to legally pass the right of commercialization of an invention, they are not sufficient for complete knowledge transmission in the process of technology transfer. Lack of efficiency of formal mechanism to end the Technology Transfer loop makes an opportunity to create innovative interpersonal and organizational connections among patentee and licensee company. With emphasize on need for further elaboration of informal mechanisms as critical and underappreciated aspect of technology transfer process, article will try to answer the questions of how to optimize knowledge transmission process in the framework of University-Industry Technology Transfer Projects? What is the theoretical basis for university-industry technology transfer process? What are organization collaborative models which can enhance overall performance by improving transmission of knowledge in University- Firm Technology Transfer process?
\end{abstract}

Key words: Technology Transfer, Patent, Tacit Knowledge, University-Firm Organizational Relations

\section{INTRODUCTION}

It is already long time that, university technology transfer, known as transferring university discoveries for the purpose of commercialization to private entities is occupying a central point in academic, governmental and industrial discussions [9]. Solution for different social and environmental problems like climate change and food processing is sought in academic research and policy makers consider technological innovations among drivers of economic development and job creation in current turbulent global situation. However, it should be noticed that only about 50 percent of patented innovations will get to market and achieve commercialization status [5] which is an indicator for challenges on the way to successful passage of an innovation from being only a concept to a demanded product in global market place.

Technology transfer has been defined as: "Shifting or relocating discoveries, inventions, and innovations from the research laboratory to the market place" [28]. This phenomenon will take place within the complementary frameworks of formal and informal process [37].

Formal technology transfer takes place through patenting and licencing of patented academic inventions to third parties for the purpose of commercialization while informal process known as complementary step for formal technology transfer includes: academic presentations, scientific publications, scientific consulting, internships, informal meetings, personal contacts and research contracts [1]. Despite the fact that formal technology transfer process and licencing of patented innovations to third party is the main legal tool for safeguarding rights of academic inventors in commercialization of their inventions, it is not sufficient for transmitting tacit knowledge which is necessary in exploitation of transferred technology. Existence of reciprocal and complementary relations between formal and informal technology transfer process has resulted in formation of different models for university-industry organizational collaboration or even integration where licensee firms keep contact with academic inventors after gaining legal right for commercialization of their patented invention. In the same vein with above mentioned argument, current paper argues that despite necessity for patents to legally pass the right of commercialization of an invention, they are not sufficient for complete knowledge transmission in the process of technology transfer. Insufficiency of formal mechanism to complete the technology transfer loop gives way to in- 
novative interpersonal and organizational links among patentee and licensee frim [36]. With emphasize on need for further elaboration of informal mechanisms as critical and underappreciated aspect of technology transfer process, article will try to answer the question of how to optimize knowledge transmission process in the framework of university-industry technology transfer projects? What is the theoretical basis for university-industry technology transfer process? What are organization collaborative models which can enhance knowledge transmission in university-frim technology transfer process? The paper starts with explaining current theoretical frameworks applied to university-industry relations in technology transfer process. Including, market oriented theory as well as theory of the firm. Part two will analyse different effective factors in successful transmission of knowledge in technology transfer projects including issues relevant to transmission of explicit and tacit knowledge. Part three will explore organizational collaborative models between university and industry for the purpose of facilitating knowledge transfer process and finally, existing criticisms on the way of organizational integration in university-industry technology transfer process will be explored.

\section{THEORETICAL FRAMEWORK FOR UNIVERSITY-INDUSTRY RELATIONS IN TECHNOLOGY TRANSFER PROCESS}

Formal technology transfer is highly dependent on markets to absorb inventions from university and let them to be commercialized by firms. There is no doubt that only achieving an invention is not a guarantee for its successful commercialization. In fact, taking an invention to market is in need of considerable amount of efforts [19]. Theory of the firm helps us to explore different possibilities for commercialization of an invention by providing two main paths for this purpose: commercialization of inventions might take place either by vertical integration or market based production.

Vertical integration is linking the upstream research and development activities with downstream production, marketing and distribution function [23]. Historically, vertical integration was popular in mid twenty century when companies like AT\&T and IBM managed to combine all functions of the value chain in the framework of one firm. Despite the fact that in theory, it is perfectly possible to vertically integrate a university based research unit with a commercial firm, many practical obstacles like different corporate cultures, transaction costs, and conflicts and interest prevent such full scale takeover of academic research units by commercial firms. However, obstacles do not prevent formation of different levels of structural integration and collaboration between universities and firms as they will be explained in next part of the paper.

As an alternative to vertical integration, different entities can perform upstream and downstream functions in the value chain independently and share intermediate goods on the basis of market demand [34]. Example of such market oriented interaction in commercialization of inventions can be seen in business model used by firms in biotechnology industry. While biotechnology labs develop prototype medicine by conducting upstream research and development functions, clinical trial, production, marketing and distribution of products are licenced to pharmaceutical companies.

The market based commercialization approach keeps universities and commercial firms separate from each other where each of which maintains respective specialities and interact on the basis of market demand to transfer technology from one to another [37].

Process of market exchange between firm and university happens with help of patent which provide possibility to commodify technology or trade it in the marketplace [6]. Patent law is appreciated and recognized in different nations and even some nations have regulated ownership of the achievements from publicly funded research in a way that universities are permitted to keep the ownership of patents for their inventions and licence them to commercial firms (example is Bayh-Dole Act in the United States of America ). Development of technology transfer offices in different universities is result of market orientation attitude in university technology transfer. These offices follow the mandate of marketing technologies by collecting technological disclosures, coordinating patent prosecution and conducing licence negotiation for patent with commercial firms. Market based technology transfer is in compliance with patent law which confirms patents are solely meant to reward invention not commercialization [51] granting patent does not require the production of invention and event production of prototype can take place after licencing out the patent to a commercial firm [15]. Market orientation of licencing patents in university-firm technology transfer process is also in accordance with prospect theory which confirms that grant of patent to an early stage invention will prevent simultaneous work of multiple parties on discovery and development of same technology [10]. Effective function of patent markets is implicit in prospect theory. It confirms possibility to licence a patent to single or multiple licences where the patentee does not have possibility to commercialize the invention by her own [32]. Therefore, some commentators consider patenting and licencing as synonymous to technology transfer [35].

However, the market oriented technology transfer model has been criticized heavily by some scholars. Main criticisms to this model of technology transfer applying to university-firm technology transfer process include: transaction costs and effectiveness of patent disclosure.

1. Transaction Costs. Early theoretical frameworks for technology transfer considered that it "has no real cost and amounts to little more than the permissions to infringe patents" [4]. However, this concept is challenged seriously as costs of identifying parties, technology valuation, and negotiating the deal can increase expenses, complexity of process and duration of the transferring technology significantly. Strategic behaviour should be added to above mentioned list as it can increase costs of transaction particularly in situation of bilateral monopoly [43]. Empirical studies show the range of transaction costs technology transfer process between 2 to 59 percent with average 19 percent of project cost [58]. As a common criticism, transaction costs also apply to university-firm technology transfer process where capability of university in finding possible licensee companies easily and with low costs is prevailing idea.

2. Effectiveness of Patent Disclosures: Patents do not require all details of their invention to be documented. Therefore, patent specifications are not equal to production specifications [12]. According to American patent law, patents are supposed to be read and understood by Person Having Ordinary Skill in The Art (PHOSITA) who is someone familiar with the industry. Patent disclosures are mostly full of formalism and jar- 
gon which make them difficult for being understood [50]. From the strategic point of view, patentees are better off to provide unclear and vague disclosures in order to reveal as little information as possible and cripple competitors in taking advantage of invention [22].

However, critics on efficiency of patent disclosures consider incurring such costs necessary but not sufficient in technology transfer process due to lack of teaching effects in patents [26]. Transaction costs critics consider necessity for establishment of long term relations between licensor and licensee and incur costs of defining potential licences, negotiations, taking appropriate measures against strategic behaviours in order to effectively transfer the technology.

\section{FACTORS AFFECTING SUCCESS OF TECHNOLOGY TRANSFER IN UNIVERSITY-INDUSTRY RELATIONS}

Despite the fact that market's demand considered as fundamental concept in successful technology transfer, personal relations is of an undeniable importance in this process. As a matter of fact, personal relations between university inventors and potential licences firms will result in considerable reduction of transaction costs in technology transfer as well as overcoming insufficiency of patent in process of tacit knowledge transfer. Apart from personal relations, scholars consider some other important factors in success of technology transfer process [37]: capacity of licensee firm for internalizing transferred technology, geographical proximity and finally, relationship based concept of technology transfer. This section of the paper will discuss above mentioned factors and their role in successful technology transfer process.

\section{Personal relations in identifying licensees}

While role of markets is obvious in transfer of technology, personal relations also play a crucial role in finding potential licensees in thin university invention markets. Later, such relations become even more important in the process of tacit knowledge transfer from inventors to licensees. It is difficult to licence patented university inventions [54]. The naive approach to licencing process of university inventions considers that after patenting the invention, patentee will wait for potential commercial firms to come and propose for licencing it. Although, some universities might take such strategy in marketing their inventions [9], this is far away from realistic process of technology transfer in university-industry relations. Small market for licencing university inventions has been mentioned in numerous surveys [59]. Therefore, existence of personal relations is an important factor in defining potential firms suitable for licensing an invention. Based on the traditional division of labour, university inventors provide Technology Transfer Offices (TTO) with patents ready to be licenced and continue their own academic research and leaving the marketing and legal aspects of technology transfer to TTO. However, in reality, surveys show active involvement of faculty inventors in marketing of their inventions [29]. University faculty members are highly capable of marketing their inventions due to their technical knowledge and scientific competencies which helps them to recognize commercialization opportunities [40].

Therefore, real picture of university-firm technology transfer is different from what has been suggested by market orientation concept.

\section{Tacit Knowledge}

University inventors play a significant role in transferring technical knowledge to licensees of their patented inventions. From the perspective of market oriented technology transfer process, inventor exchanges legal rights of exploiting an invention with consideration in the format of licencing a patent. However, there is a general agreement that patents do not disclose sufficient knowledge about invention as much relevant knowledge about invention will remain undocumented and tacit. Transferring tacit knowledge is a serious challenge in university-industry technology transfer process [37]. In technical language, tacit knowledge is known as implicit knowhow relevant to an invention which is not possible for inventor to articulate it in written format [27]. In fact, some scholars have defined technology as "complex mix of codified data and poorly defined, tacit know-how" [46]. Due to early stage nature of faculty inventions, tacit knowledge plays an important role in effective university-firm technology transfer [2]. Even patenting an invention will not reduce the importance of tacit knowledge transfer as patents are generally codified in an incomplete manner [16]. The personal nature of tacit knowledge creates challenges on the way to its effective transmission. Since transfer of tacit knowledge "requires, by definition, a face to face contact" [14], human relation is considered as the best way for its transmission [33]. In this vein, importance of faculty involvement in university-firm technology transfer process has been confirmed by numerous surveys. In one survey from 62 studied TTO offices in US universities it was confirmed that 71 percent of licensed inventions could not be commercialized without faculty involvement in technology transfer process [30]. Another survey showed faculty involvement in 40 percent of licencing agreements [44]. Considering legal mechanisms like royalties for faculty inventors can facilitate the process of tacit knowledge transmission by further involving them in the technology transfer process.

\section{Capacity of licensee firm for internalizing transferred technology}

Another important factor in achievement of technology transfer goals is readiness of licensee firm for receiving cognitive aspects of invention [13]. Such readiness is known as absorption capacity of the firm referring to existence of organizational capability (mostly availability of tacit knowledge) to exploit innovation [13]. Value of improving absorption capacity by establishing relations with academia has been proven in many industries [39]. For example success of innovative medicines in pharmaceutical industry depends strongly on developing knowledge base of the firm in collaboration with academia. The same strong collaboration has been seen between biotechnology firms and academia which intends to "enhance their capacity for learning" [47]. Important role of personal relations between academic inventors and licensee firms in improvement of absorption capacity of the firm is another reason for questioning validity of market oriented theory of technology transfer

\section{Geographic Proximity}

With reference of market oriented theory of universityfirm technology transfer, technologies are defined commodities with low transaction costs which are sufficiently disclosed by patent. Therefore, licencing process should not 
be affected by geographical factors. Tendency of innovative institutes to cluster in a proximate geographical distance is known from 19th Century as "agglomeration economies" where firms exploit innovation spill overs in close by companies in the same region and similar industry [42]. Tacit knowledge [24] has sticky nature [57]. Therefore, communication between inventors who have acquired such sticky knowledge and licences of the technology deemed to be constant and it will be much easier established within short geographical distances [25]. Silicon Valley and Rout 128 in the USA are examples of such geographic clustering. Access to financial resources can be mentioned as another factor for existence of geographical clusters in university-firm technology transfer process as availability of venture capitalists has been considered among important reasons behind growth of start-ups [56].

\section{UNIVERSITY-INDUSTRY COLLABORATIVE MODELS IN TECH- NOLOGY TRANSFER PROCESS}

Based on the discussion above, it is possible to conclude that in contrast with market based concept which considers licencing of patents sufficient for formal transfer of technology, difficulties on the way of transmission of tacit knowledge, other problems like transaction costs and strategic behaviour of parties promote the establishment of ongoing relations between patentees and licensees in the course of university-firm technology transfer process. In order to exploit such relations, theory of the firm proposes different models of organizational integration ranging from formation of collaborative networks to complete consolidation [37]. This section provides that despite importance of patents and licences, different levels of organizational integration play a significant role in transmission of tacit knowledge and commercialization of academic inventions. University-firm integration may appear in different forms [45], starting from sponsoring scientific research and using faculty as consultants to opening an start-up company as an example for consolidation of academic research and entrepreneurial practice. However, we need to differentiate above mentioned levels of consolidation from vertical integration. In fact, integration in the context of our discussion can be annexing a set of contractual relations (like hiring faculty as consultant) to another contract (licencing a patent). Therefore, in current discussion, integration is about fading organizational boundaries to let firms maximize benefits from academic resources [27].

\section{Sponsored Research}

Commercial sponsorship of academic research is an important way in increasing effectiveness of university-firm technology transfer process which functions by exposing sponsor firms to latest academic discoveries and increasing absorptive capacity of them. In practice, sponsorship promotes joint research between industrial and academic scientists that is key factor in effective transmission of tacit knowledge transfer [7]. As an important aspect of sponsorship, organizational integration takes place in different forms including: posting of industrial scientists in academic laboratories, employing academic faculty in industrial labs, and formation of hybrid organizations for the purpose of mediating sponsored research in university like Whitehead Institute of Biomedical Research at MIT [3]. Outcome of sponsored research is mostly patented innovations while scientific expertise of academic inventors help technical advancement of product, insider knowledge of commercial firm will guide the project towards more commercial appropriation.

Sponsored research is a common form of university-firm organizational integration and results of surveys show about one third of university licences enjoy funding provided by licensee firm [30]. Therefore, sponsored research keeps the relation between patentee and licensee ongoing and promotes transmission of the tacit knowledge.

Direct involvement of academic scientists in commercialization process

There is no doubt that direct interaction with faculty inventors will exponentially increase that chance of exploiting a new technology. A survey shows that 18 percent of failures in university-firm technology transfer process has been considered by licensee firms as a result of noninvolvement of faculty members in project [59].

Engagement of faculty inventors in commercialization process takes place in different forms. In many occasions, faculty inventor will be hired as consultant by licensee firm. Surveys show that hiring faculty inventor as consultant is the most common way used by licensee firms for the purpose of tacit knowledge transfer [59]. Particularly in startups, faculty members can be a permanent technical advisor or even a board member of licensee firms [52]. In fact, biotechnology industry is a good example for early involvement of academic scientists in successful commercialization of innovative products.

Apart from improving the effectiveness of tacit knowledge transfer, academic inventors might be involved in organization of licensee firms for other reasons like access to network of scientists or providing signal to financial market [45].

\section{Formation of Start-up Companies}

Faculty inventors are frequently involved in start-up companies which licensee university patents. According to surveys, 12 percent of university patents are transferred to private sector by licencing to start-up companies [17] where universities confirm supporting such arrangements [48]. Complete integration of upstream academic research with downstream commercialization activities merge within the framework of establishing a new firm by faculty inventor [40]. This idea is supported by commentators because most of new inventions are highly dependent on tacit knowledge, therefore, involvement of inventor as an entrepreneur in the commercialization of them will positively affect the technology transfer process [17].

\section{Institutional Linkages}

Institutional linkage is a further step which universities take in transmitting tacit knowledge in the process of university-firm technology transfer. Main forms of institutional linkages are found when universities establish business incubators or take equity in licensee firms. Currently, many universities are involved in establishment of business incubators to promote the commercialization of new inventions [41]. The main objective behind establishment of such incubators is facilitating professional relations between university inventors and entrepreneurs to help commercialization process [17]. Also universities increasingly take equity stakes in the firms which licence their inventions. Such practice is more popular when licensing new technologies to start-ups facing with cash deficit [17]. Some surveys show that almost 25 percent of licencing technology transfer of universities includes equity transfer [30]. Generally 
Management Systems in Production Engineering 2(22)/2016

H. ALAVI, P. HĄBEK - Optimizing outcome in the university-industry technology transfer projects

speaking, such deals will help universities and licensee firms to align their objectives towards more effective transmission of tacit knowledge [20]. Also, gaining equity interest provides access to entire income in the firm for university rather than access to revenue from single project which is another motivation for scientific inventors to increase effectiveness of whole technology transfer process [20].

\section{EXISTING CRITICISM REGARDING UNIVERSITY INDUSTRY INTEGRATION}

Despite the fact that close interactions between academic inventors and licensee firms are considered crucial in university-firm technology transfer process, such converging relations create valid concerns among scholars [55]. Among others following criticisms are worth of attention: profit seeking interests will affect research agendas and shift them towards more commercial than scientific areas of inquiry [21], involvement in commercial research will increase bias in investigations [53], reduce academic productivity [8], provide incentives for manipulating research outcomes [49]. Also reducing academic freedom [38], emergence of conflict of interest [60], reducing teaching quality [31] and reducing public trust in universities [60] are among other scholar criticisms on close university-industry organizational relations. Particular attention has been paid to sponsored research which is criticized because of risky governance structures of sponsored research agreements [61], possibility of manipulating research results and raising issue of secrecy by sponsors [18].

Given the specific nature of academic institutions, it is impossible to rely on market oriented theory for commercialization of faculty inventions and at the same time, universities should prevent falling in the trap of undue integration with commercial entities via implementation of proper safeguards in university-technology technology transfer process. Among others, such safeguards can be listed as: limiting time of faculty consulting [3], limiting faculty ability to take managerial positions in licensee companies [3], restricting secret research [18], keeping the balance of interests in governance of sponsored research agreements [61] and taking board member positions in budgeting committees [11].

\section{CONCLUSION}

While theories of patent and technology transfer are based on market function for law cost efficient and effective transfer patented technology, current article tried to raise existing difficulties on the way of commercializing academic inventions by attracting attention to insufficiencies of patents and market oriented concept of technology transfer. In this vein, different factors for increasing personal involvement of faculty inventors as well as models of organizational integration between universities and licensee firms which boost personal involvement of university faculty in commercialization process of their inventions were explained. Finally, paper pointed at concerns over different models of structural integration between academic institutions and commercial firms in the framework of technology transfer process. From all above mentioned discussion, it is possible to conclude that personal involvement of faculty inventors has significant importance in commercialization process of inventions and universities should keep a prudent balance in formulation of their collaboration with licensee firms.

\section{REFERENCES}

[1] Agrawal. „University-to-Industry Knowledge Transfer: Literature Review and Unanswered Questions", in International Journal of Management Reviews, vol. 3 (4), December 2001, pp. 285-302.

[2] Agrawal. „Engaging the Inventor: Exploring Licensing Strategies for University Inventions and the Role of Latent Knowledge", in Strategic Management Journal, vol. 27(1), January 2006, pp. 63-79.

[3] N.S. Argyres and J.P. Liebeskind. „Privatizing the Intellectual Commons: Universities and the Commercialization of Biotechnology", in Journal of Economic Behavior and Organization, vol. 35(4), May 1998, pp. 427 454.

[4] Arora. „Licensing Tacit Knowledge: Intellectual Property Rights and the Market for Know-How", in Economics of Innovation and New Technology, vol. 4(1), 1995, pp. 41-60.

[5] R.L. Beck. "Competition for Patent Monopolies", in Research in Law and Economics, vol. 3, 1981, pp. 91 100.

[6] J. Bessen. „Patents and the Diffusion of Technical Information", in Economics Letters, vol. 86(1), January 2005, pp. 121-128.

[7] D. Blumenthal. „Academic-Industrial Relationships in the Life Sciences", in New England Journal of Medicine, vol. 349(25), December 2003, pp. 2452-2459.

[8] D. Blumenthal et al., „Participation of Life-Science Faculty in Research Relationships with Industry", in New England Journal of Medicine, vol. 335(23), December 1996, pp. 1734-1738.

[9] Bozeman. „Technology Transfer and Public Policy: A Review of Research and Theory", in Research Policy, vol. 29(4-5), April 2000, pp. 627-655.

[10] D.L. Burk and B.H. McDonnell. „The Goldilocks Hypothesis: Balancing Intellectual Property Rights at the Boundary of the Firm", in University of Illinois Law Review, vol. 2007(2), 2007, pp. 575-636.

[11] Burstein and D. Bok. Universities in the marketplace: The commercialization of higher education, Princeton University Press, 2003.

[12] CFMT, Inc. v. YieldUP Int'I Corp., 349 F.3d 1333, 1338 (Fed. Cir. 2003)

[13] W.M. Cohen and D.A. Levinthal. „Absorptive Capacity: A New Perspective on Learning and Innovation", in Administrative Science Quarterly, vol. 35(1), March 1990, pp. 128-152.

[14] H.M. Collins. „The TEA Set: Tacit Knowledge and Scientific Networks", in Science Studies, vol. 4(2), April 1974, pp. 165-185.

[15] Ch.A. Cotropia. „The Folly of Early Filing in Patent Law", in Hastings Law Journal, vol. 61(1), November 2009, pp. 72-82.

[16] R. Cowan and D. Foray. "The Economics of Codification and the Diffusion of Knowledge", in Industrial and Corporate Change, vol. 6(3), February 1997, pp. 595622.

[17] Di Gregorio and S. Scott. „Why Do Some Universities Generate More Start-Ups Than Others?" in Research Policy, vol. 32(2), February 2003, pp. 209-227.

[18] R.S. Eisenberg. "Academic Freedom and Academic Values in Sponsored Research", in Texas Law Review, vol. 66, March 1988, pp. 1363-1404. 
[19] R.S. Eisenberg. „Patents and the Progress of Science: Exclusive Rights and Experimental Use", in University of Chicago Law Review, vol. 56, 1989, pp. 1017-1086.

[20] M. Feldman et al., „Equity and the Technology Transfer Strategies of American Research Universities", in Management Science, vol. 48(1), January 2002, pp. 105-121.

[21] B.M. Frischmann. „Commercializing University Research Systems in Economic Perspective: A View from the Demand Side", in University Entrepreneurship and Technology Transfer: Process, Design, and Intellectual Property, G.D. Libecap, Stamford (CT): JAI Press, pp. 155-186.

[22] J.C. Fromer. „Patent Disclosure”, in lowa Law Review, vol. 94(2), February 2009, pp. 539-606.

[23] R.J. Gilson et al., „Contracting for Innovation: Vertical Disintegration and Interfirm Collaboration", in Columbia Law Review, vol. 109(3), April 2009, pp. 431-502.

[24] Gorga and M. Halberstam. „Knowledge Inputs, Legal Institutions, and Firm Structure: Towards a Knowledge Based Theory of the Firm", in Northwestern University Law Review, vol. 101(3), April 2007, pp. 1123-1144.

[25] Hippel. „Sticky Information and the Locus of Problem Solving: Implications for Innovation", in Management Science, vol. 40(4), April 1994, pp. 429-439.

[26] T.R. Holbrook. „Possession in Patent Law”, in Southern Methodist University Law Review, vol. 59(1), January 2006, pp. 126-131.

[27] J. Howells. „Tacit Knowledge. Innovation and Technology Transfer", in Technology Analysis \& Strategic Management, vol. 8(2), June 1996, pp. 91-106.

[28] H. Irwin and E. More. „Technology Transfer and Communication: Lessons from Silicon Valley, Route 128, Carolina's Research Triangle and Hi-Tech Texas", in Journal of Information Science, vol. 17(5), October 1991, pp. 273-280.

[29] C. Jansen and H.F. Dillon. „Where Do the Leads for Licenses Come From? Source Data from Six Institutions", in Industry and Higher Education, vol. 14(3), June 2000, pp. 150-156.

[30] R. Jensen and M. Thursby. „Proofs and Prototypes for Sale: The Licensing of University Inventions", in American Economic Review, vol. 91(1), March 2001, pp. 240259.

[31] M. Kenney. Biotechnology: The University Industrial Complex, New Haven(CT): Yale University Press, 1986.

[32] E.W. Kitch. "The Nature and Function of the Patent System", in Journal of Law and Economics, vol. 20(2), October 1977, pp. 265-290.

[33] B. Kogut and U. Zander. „Knowledge of the Firm, Combinative Capabilities, and the Replication of Technology", in Organization Science, vol. 3(3), August 1992, 383-397.

[34] Krattiger et al. Intellectual Property Management in Health and Agricultural Innovation: A Handbook of Best Practices, MIHR and PIPRA, 2007.

[35] L.R. de Larena. „The Price of Progress: Are Universities Adding to the Cost?", in Houston Law Review, vol. 44, July 2006, pp. 1373-1375.

[36] P. Lee. „Contracting to Preserve Open Science: Consideration-Based Regulation in Patent Law", in Emory Law Journal, vol. 58(4), October 2009, pp. 889-976.

[37] P. Lee. „Transcending the tacit dimension: Patents, relationships, and organizational integration in tech- nology transfer", in California Law Review, vol. 100(6), December 2012, pp. 1503-1572.

[38] R.L. Lieberwitz. „The Marketing of Higher Education: The Price of the University's Soul", in Cornell Law Review, vol. 89, March 2004, pp. 763-800.

[39] K. Lim. „The Many Faces of Absorptive Capacity: Spillovers of Copper Interconnect Technology for Semiconductor Chips", in Industrial and Corporate Change, vol. 18(6), December 2009, pp. 1249-1284.

[40] Lockett et al., „Technology Transfer and Universities' Spin-Out Strategies", in Small Business Economics, vol. 20(2), March 2003, pp. 185-200.

[41] G.D. Markman et al., „Entrepreneurship and University-Based Technology Transfer", in Journal of Business Venturing, vol. 20(2), March 2005, pp. 241-263.

[42] Marshall. Principles of Economics, 8th ed., London: Macmillan and Co., 1920.

[43] R.P. Merges. „Of Property Rules, Coase, and Intellectual Property", in Columbia Law Review, vol. 94(8), December 1994, pp. 2655-2673.

[44] D.C. Moweryt et al., Ivory Tower and Industrial Innovation: University-Industry Technology Transfer Before and After the Bayh-Dole Act, Stanford (CA): Stanford University Press, 2004.

[45] Murray. „Innovation as Co-evolution of Scientific and Technological Networks: Exploring Tissue Engineering", in Research Policy, vol. 39(8-9), December 2002, 1389-1403.

[46] J.E. Oxley. „Appropriability hazards and governance in strategic alliances: A transaction cost approach", in Journal of Law, Economics, and Organization, vol. 13 (2), 1997, pp. 387-409.

[47] W.W. Powell. „Inter-organizational Collaboration in the Biotechnology Industry", in Journal of Institutional and Theoretical Economics, vol. 152(1), March 1996, pp. 197-215.

[48] J.B. Powers and P.P. McDougall. „University Start-Up Formation and Technology Licensing with Firms That Go Public: A Resource-Based View of Academic Entrepreneurship", in Journal of Business Venturing, vol. 20 (3), May 2005, pp. 291-311.

[49] E. Press and J. Washburn. "The Kept University”, in Atlantic Monthly, vol. 285(3), March 2000, pp. 39-54.

[50] S.B. Seymore. „The Teaching Function of Patents”, in Notre Dame Law Review, vol. 85(2), 2010, pp. 621669.

[51] T. Sichelman. "Commercializing Patents", in Stanford Law Review, vol. 62(2), January 2010, pp. 341-413.

[52] D.S. Siegel et al., „Toward a Model of the Effective Transfer of Scientific Knowledge from Academicians to Practitioners: Qualitative Evidence from the Commercialization of University Technologies", in Journal of Engineering and Technology Management, vol. 21(12), March-June 2004, pp. 115-142.

[53] H.T. Stelfox et al., „Conflict of Interest in the Debate over Calcium-Channel Antagonists", in New England Journal of Medicine, vol. 338(2), January 1998, pp. 101 $-106$.

[54] P.M. Swamidass and V. Vulasa. „Why University Inventions Rarely Produce Income? Bottlenecks in University Technology Transfer", in The Journal of Technology Transfer, vol. 34(4), August 2009, pp. 343-363.

[55] L.G. Zucker and M.R. Darby. "Star Scientists and Institutional Transformation: Patterns of Invention and 
Innovation in the Formation of the Biotechnology Industry", Proc. of the National Academy of Sciences, vol. 93(23), November 1996, pp. 12709-12716.

[56] L.G. Zucker et al., „Intellectual Human Capital and the Birth of U.S. Biotechnology Enterprises", in The American Economic Review, vol. 88(1), March 1998, pp. 290306.

[57] L.G. Zucker et al., „Commercializing Knowledge: University Science, Knowledge Capture, and Finn Performance in Biotechnology", in Management Science, vol. 48(1), January 2002, pp. 138-153.

[58] D.J. Teece. „Technology Transfer by Multinational Firms: The Resource Cost of Transferring Technological Know-How", in The Economic Journal, vol. 87(346), June 1977, pp. 242-261.
[59] J.G. Thursby and M.C. Thursby. „Are Faculty Critical? Their Role in University-Industry Licensing", in Contemporary Economic Policy, vol. 22(2), April 2004, pp. 162-178.

[60] D.J. Triggle. „Patenting the Sun: Enclosing the Scientific Commons and Transforming the University - Ethical Concerns", in Drug Development Research, vol. 63 (3), November 2004, pp. 139-149.

[61] J. Washburn. „Big Oil Buys Berkeley: The BP-UC Berkeley Research Deal Pushes Academic Integrity Aside for Profit", in Los Angeles Times, 24 March 2007.

\footnotetext{
Hamed Alavi, MBA

Tallinn University of Technology

Akadeemia Tee 3, Tallinn 12618, ESTONIA

e-mail: hamed.alavi@ttu.ee

dr inż. Patrycja Hąbek

Silesian University of Technology, Faculty of Management and Organization, Institute of Production Engineering

ul. Roosevelta 26, 41-800 Zabrze, POLAND

e-mail: patrycja.habek@polsı.pl
} 